\title{
Hematidrosis, Hemolacria, and Gastrointestinal Bleeding
}

\author{
Artur Sérgio Gião Antunes Bruno Peixe Horácio Guerreiro
}

Gastroenterology Departament, Centro Hospitalar do Algarve, EPE, Faro, Portugal

Keywords

Gastrointestinal hemorrhage · Vasculitis · Purpura

\section{Hematidrose, Hemolacria e Hemorragia Gastrointestinal}

\section{Palavras Chave}

Hemorragia gastrointestinal · Vasculite · Purpura

A 66-year-old male was admitted to the internal medicine department for asthenia and lower-limb edema. He also reported a self-limited respiratory tract infection in the previous 3 weeks, and afterwards he developed abdominal fullness. From his medical record, we registered long-standing type 2 diabetes, and the patient was chronically treated with ramipril plus hydrochlorothiazide for hypertension.

On examination, for the exception of symmetric lower-limb edema, no other abnormalities were seen. His initial blood tests were as follows: hemoglobin $14,0 \mathrm{~g} / \mathrm{L}$; white blood cell count $8.2 \times 10^{9} / \mathrm{L}$; neutrophils $92.9 \%$; platelets $264 \times 10^{9} / \mathrm{L} ; \mathrm{Na} 134 \mathrm{mmol} / \mathrm{L} ; \mathrm{K} 4,2 \mathrm{mmol} / \mathrm{L}$;

\begin{tabular}{ll}
\hline KARGER & $\begin{array}{l}\text { (c) } 2017 \text { Sociedade Portuguesa de Gastrenterologia } \\
\text { Published by S. Karger AG, Basel }\end{array}$ \\
$\begin{array}{l}\text { E-Mail karger@karger.com } \\
\text { www.karger.com/pjg }\end{array}$ & $\begin{array}{l}\text { This article is licensed under the Creative Commons Attribution- } \\
\text { NonCommercial-NoDerivatives } 4.0 \text { International License (CC BY- } \\
\text { NC-ND) (http://www.karger.com/Services/OpenAccessLicense). } \\
\text { Usage and distribution for commercial purposes as well as any dis- } \\
\text { tribution of modified material requires written permission. }\end{array}$
\end{tabular}

blood urea nitrogen $61 \mathrm{mg} / \mathrm{dL}$; creatinine $3.3 \mathrm{mg} / \mathrm{dL}$; Creactive protein $19 \mathrm{mg} / \mathrm{L}$, and INR 1.0. Urinalysis showed $1,178.7 \mathrm{mg} / \mathrm{dl}$ of proteinuria, with $3-5 \mathrm{red}$ and white blood cells per high-power field, without dysmorphic cells. Total cholesterol $(353 \mathrm{mg} / \mathrm{dL})$ and triglyceride (261 $\mathrm{mg} / \mathrm{dL}$ ) were increased, and serum protein electrophoresis revealed hypoalbuminemia $(1.8 \mathrm{~g} / \mathrm{dL})$. In a $24-\mathrm{h}$ specimen of urine, protein was $2,716 \mathrm{mg}$.

During hospitalization, the patient developed a sudden episode of hematemesis. On physical examination, he had hemodynamic stability and epigastric tenderness without guarding or rebound tenderness. The upper endoscopy showed diffuse mucosal redness, small ring-like petechiae, submucosal hemorrhages, and superficial ulcers in the gastric body, antrum, and duodenum (Fig. 1).

There was a rapid clinical deterioration, with the development of hemolacria (bloody tears), hematidrosis (bloody sweat), macroscopic hematuria, and appearance of a palpable purpura on the lower limbs, abdomen, and trunk (Fig. 2). The patient developed multiple organ failure and required hemodialysis and mechanical ventilation. Given the clinical set, we considered the diagnosis of a vasculitis and started corticosteroids $(1,000 \mathrm{mg}$ of methylprednisolone per day). A chest high-resolution computed tomography scan was performed, and besides

Dr. Artur Sérgio Gião Antunes

Gastroenterology Department, Centro Hospitalar do Algarve, EPE

Rua Leão Penedo

PT-8000-386 Faro (Portugal)

E-Mail sergiogiao@ hotmail.com 

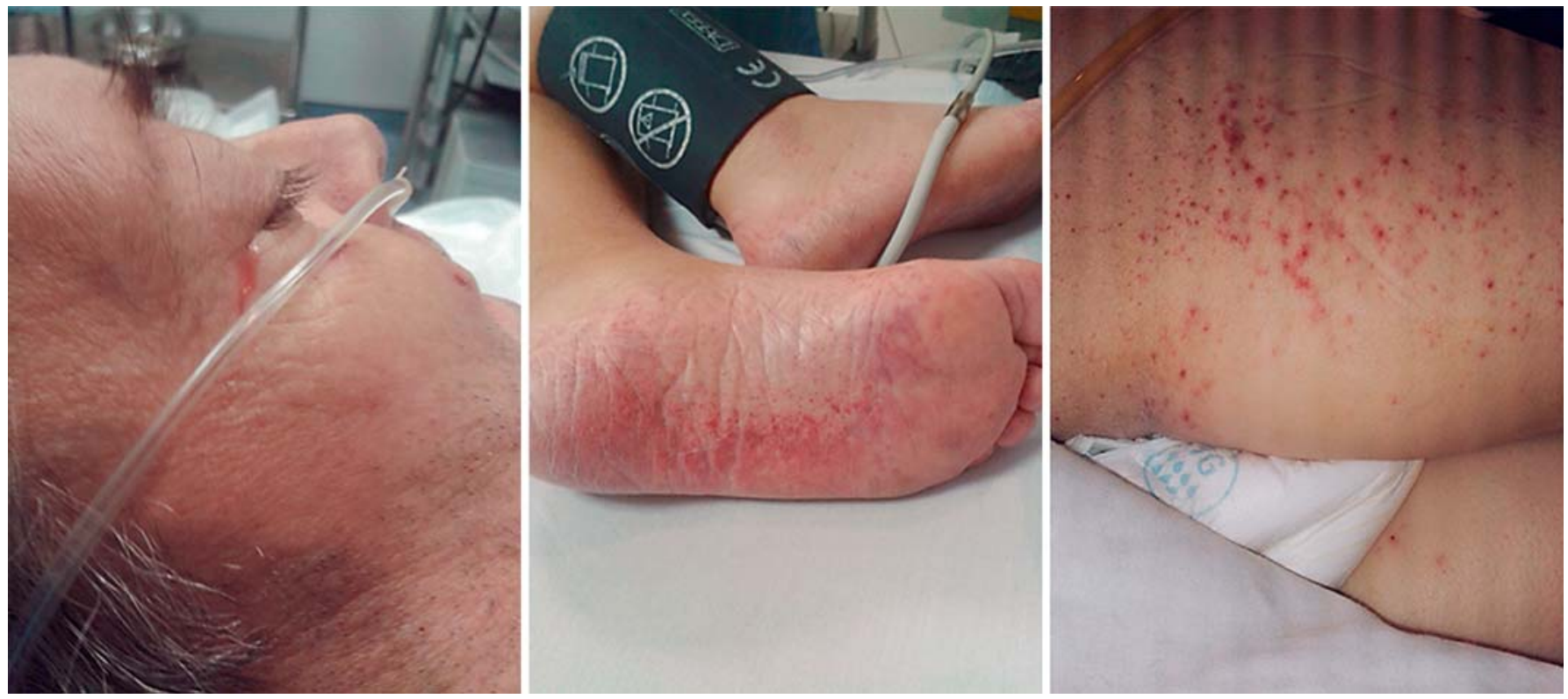

Fig. 1. Hemolacria and skin purpura.
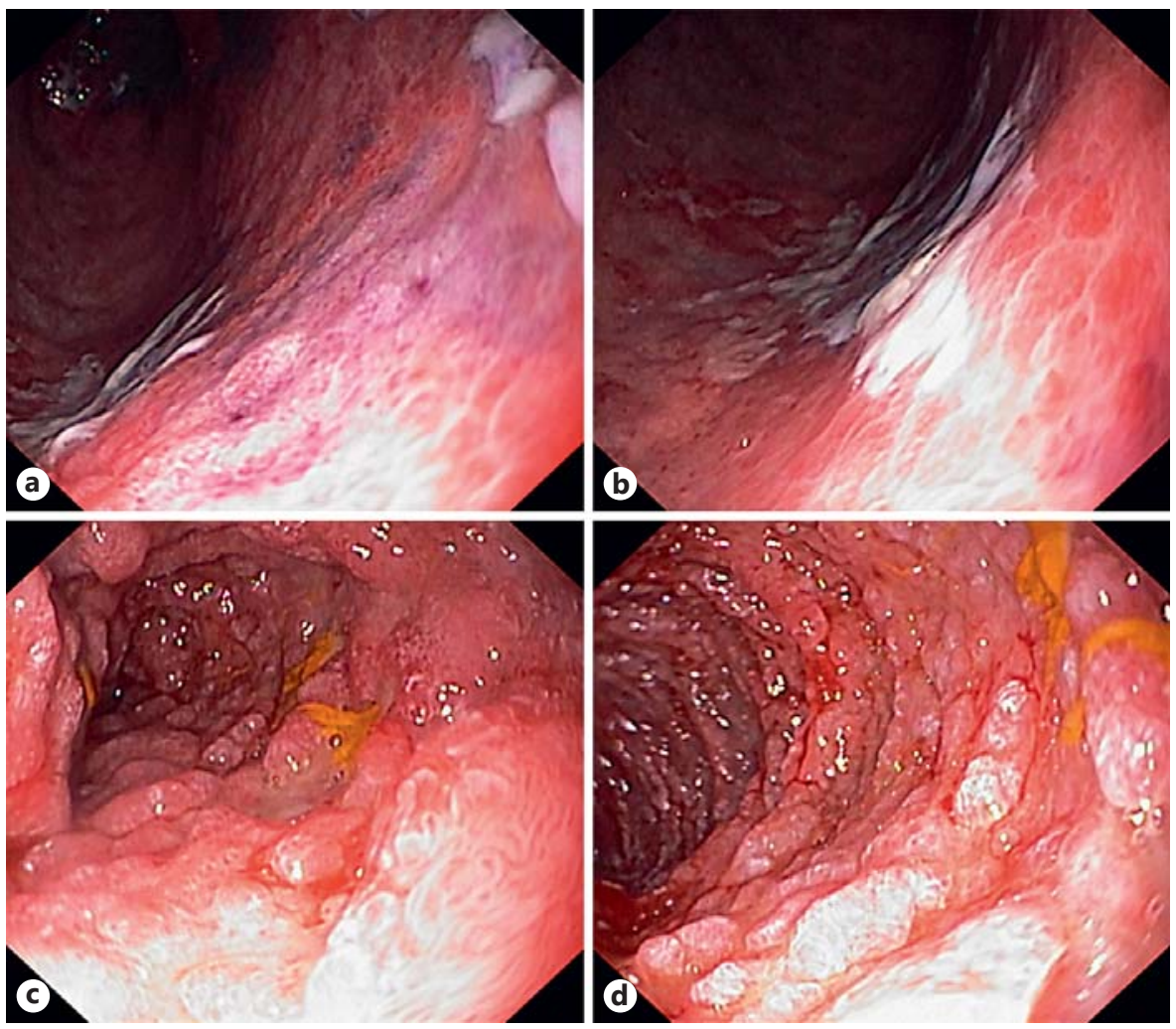

Fig. 2. Diffuse mucosal redness (a), small ring-like petechiae (b), and submucosal hemorrhages in the stomach (c) and duodenum (d) are shown. 
Fig. 3. a Duodenum biopsies showing edema, inflammatory infiltrate with neutrophilic predominance and hemorrhagic foci in the lamina propria, and areas with necrosis and bacteria. b Skin biopsies revealing leukocytoclastic vasculitis with endoluminal thrombosis.
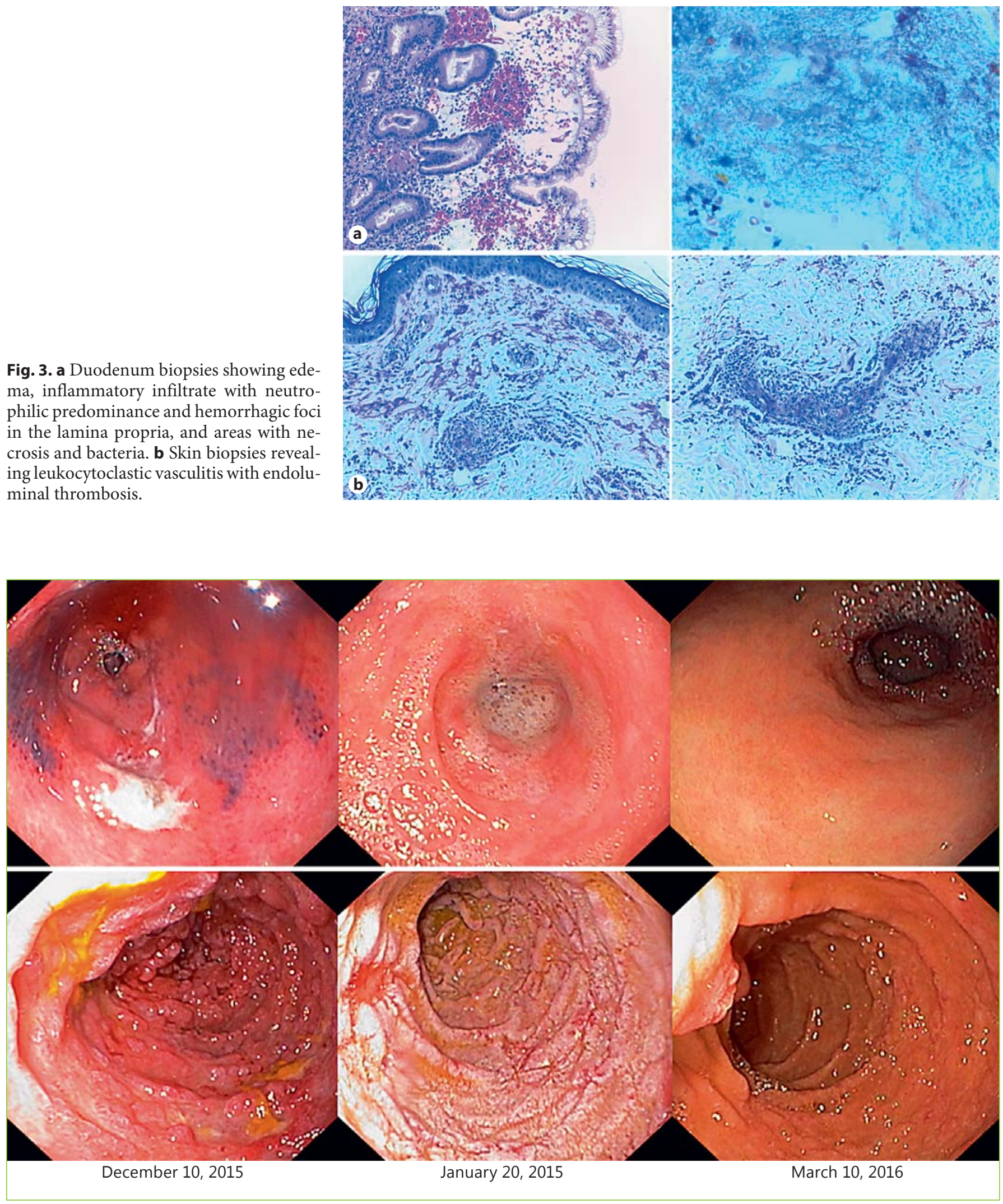

Fig. 4. Endoscopic follow-up.

Hematidrosis, Hemolacria, and Gastrointestinal Bleeding
GE Port J Gastroenterol 2017;24:301-304 DOI: $10.1159 / 000461591$ 
bilateral pleural effusion, no other abnormalities were noticed.

Serologies for HIV, hepatotropic viruses, Venereal Disease Research Laboratory test, and antistreptolysin O antibodies were negative. Blood tests for autoimmunity (antinuclear antibodies, antineutrophilic cytoplasmic antibodies, and serum cryoglobulins) and blood cultures were also normal. With corticotherapy, there was a hasty improvement, and a kidney biopsy was performed.

Histology from the stomach, duodenum, and skin (Fig. 3) was compatible with vasculitis, and the kidney biopsy with immunofluorescence showed mesangial IgA deposits. We established the diagnosis of a HenochSchönlein Purpura (HSP). The patient continued with oral prednisolone $(1 \mathrm{mg} / \mathrm{kg})$ for 3 months, and subsequent endoscopies confirmed the good evolution (Fig. 4).

HSP is an IgA-mediated small-vessel vasculitis that most commonly affects children. In adults, it is extremely rare, with an estimated incidence of $0.1-1.2$ per million. Its etiology is still unclear, but a recent history of respiratory tract infection is reported in $90 \%$ of the cases. Other precipitating factors already identified are medications (nonsteroidal anti-inflammatory drugs, angiotensinconverting enzyme inhibitors, or antibiotics), tumors (non-small cell lung cancer, prostate cancer, or hematological malignancies), food allergies, vaccinations, and insect bites [1].

Gastrointestinal involvement is common in HSP (in up to $85 \%$ of the patients), varying from colicky abdominal pain, nausea, and vomiting to intestinal hemorrhage, intussusceptions, and pancreatitis [2].

HSP should be considered in the differential diagnosis of a patient with gastrointestinal bleeding, palpable purpura, and acute renal injury $[2,3]$.

\section{Statement of Ethics}

This study did not require informed consent or review/approval by the appropriate ethics committee.

\section{Disclosure Statement}

The authors have no conflicts of interest to declare.
References
1 Watts RA, Carruthers DM, Scott DG: Epidemiology of systemic vasculitis: changing incidence or definition? Semin Arthritis Rheum 1995;25:28-34.

2 Sohagia AB, Gunturu SG, Tong TR, et al: Henoch-Schonlein purpura - a case report and review of the literature. Gastroenterol Res Pract 2010;2010:597648.

3 Juthpratuck W, Elshenawy Y, Salet H, et al: The clinical implications of adult-onset $\mathrm{He}$ noch-Schonlein purura. Clin Mol Allergy 2011;9:9. 